\title{
Study of the adhesion of microhybrid and nanohybrid diacrylic composite resins to dental hard tissues
}

\author{
Studiul adeziunii răşinilor diacrilice compozite microhibride şi nanohibride \\ la ţesuturile dure dentare
}

Bogdan Mihai Gălbinaşu1, Vlad-Cristian Grigore², Andreea-Nicoleta Ghiță",
Ion Pătraşcu1
${ }^{1}$ Catedra de Tehnologia Protezelor şi Materiale Dentare, Facultatea de Medicină Dentară,
Universitatea de Medicină şi Farmacie "Carol Davila“, Bucureşti, România
${ }^{2}$ Facultatea de Medicină Dentară, Universitatea de Medicină şi Farmacie
"Carol Davila“, Bucureşti, România
${ }^{3}$ Institutul Naţional de Cercetare-Dezvoltare pentru Metale Neferoase şi Rare, Pantelimon, România

\begin{abstract}
Objective. The aim of the present study is to compare the adhesive capacity of the microhybrid and nanohybrid diacrylic composite resins to enamel, dentin and cement.

Materials and method. Standardized cavities were made at the cervical level on the vestibular surfaces of 8 maxillary third molars without caries or fractures. The cavities were filled with microhybrid (Filtek Z250 - 3M ESPE), respectively nanohybrid composites (Filtek Z550 - 3M ESPE), half of the teeth also receiving an intermediate layer of flowable composite (Gradia Direct LoFlo - GC). All of them were subjected to a thermocycling process (300 cycles in water of $5^{\circ} \mathrm{C} / 55^{\circ} \mathrm{C}$ ). After the isolation of the teeth with nail polish, they were introduced into $1 \%$ methylene blue for 24 hours. Subsequently, they were embedded in an epoxy resin (EpoThinTM 2 - Buehler), polished and sectioned mesiodistally with Beta Grinder/Polisher-Buehler. Sections were selected where the greatest degree of methylene blue penetration was detected to be analyzed by optical polarized light microscopy (Axio Imager A1m - Zeiss).

Results. All teeth showed microinfiltration of the cement, while only half showed it also in enamel. There are no microinfiltration differences between micro- and nanohybrid composite resins. The intermediate layer of flowable composite does not influence microinfiltration.
\end{abstract}

Keywords: adhesive capacity, microhybrid, nanohybrid, diacrylic composite resins, enamel, dentin, cement

\section{REZUMAT}

Obiectiv. Scopul prezentului studiu este de a evalua comparativ capacitatea adezivă a răşinilor diacrilice compozite micro- şi nanohibride la nivelul smalţului, dentinei, respectiv cementului.

Material şi metodă. La nivelul a 8 molari trei maxilari, fără carii sau fracturi, au fost realizate cavităţi standardizate la nivel cervical pe suprafeţele vestibulare. Cavităţile au fost obturate cu răşini diacrilice compozite microhibride (Filtek Z250 - 3M ESPE), respectiv nanohibride (Filtek Z550 - 3M ESPE), jumătate dintre acestea având şi un strat inter-mediar de compozit fluid (Gradia Direct LoFlo - GC), şi supuse unui proces de termociclare (300 de cicluri în apă de $5^{\circ} \mathrm{C} / 55^{\circ} \mathrm{C}$ ). După izolarea dinţilor cu lac, aceștia au fost introduşi în albastru de metilen $1 \%$ timp de 24 de ore. Ulterior au fost înglobaţi într-o răşină epoxidică (EpoThinTM 2 - Buehler), lustruiţi şi secţionaţi meziodistal cu ajutorul Beta Grinder/Polisher - Buehler. S-au ales secţiunile unde era surprins cel mai mare grad al penetrării albastrului de meti-len pentru a fi analizate prin microscopie optică cu lumină polarizată (Axio Imager A1m - Zeiss).

Rezultate. Toţi dinţii au prezentat microinfiltraţie la nivelul cementului, în timp ce doar jumătate au prezentat şi la nivelul smalţului. Nu există diferenţe din punct de vedere al microinfiltraţiei între obturaţiile cu răşini diacrilice compozite micro- şi nanohibride. Stratul intermediar de compozit fluid nu influenţează microinfiltraţia.

Cuvinte cheie: capacitate adezivă, răşini diacrilice compozite, microhibride, nanohibride, smalţ, dentină, cement

\section{INTRODUCERE}

Utilizarea răşinilor diacrilice compozite în restaurările directe a avut o creştere importantă în ultime- le decenii. Acest lucru este pus pe seama evoluţiei adezivilor, a particulelor anorganice din umplutură şi a matricei organice, care au permis obţinerea unei legături adezive cu ţesuturile dure dentare (1-4). 
$\mathrm{Cu}$ toate acestea, se poate vorbi despre o adeziune eficientă doar la nivelul smalţului, dentinei şi cementului, din cauza structurii mai slab mineralizate, şi încă reprezintă o provocare încercarea de a realiza o închidere etanşă la nivelul dinte-obturaţie (5-7). Aşadar, principalul eşec al restaurărilor directe cu răşini diacrilice compozite constă în apariţia microinfiltraţiei marginale, consecinţă a lipsei adeziunii la nivelul tuturor ţesuturilor dure dentare (8).

Smalţul este cel mai dur şi mineralizat ţesut al organismului, din punct de vedere chimic fiind constituit dintr-o parte anorganică (96\%), una organică (1\%) şi apă (3\%) (9). Adeziunea se realizează prin intermediul microretenţiilor formate la nivelul acestuia în urma gravării acide, lucru posibil datorită structurii specifice, intens mineralizată. Pe lângă acest mecanism principal însă, s-a observat şi posibilitatea realizării unei legături chimice cu hidroxiapatita prin reacţia de chelare cu ionii de calciu, fosfat sau grupări hidroxil $(5,10)$.

Dentina însă este un ţesut dur compus din aproximativ $70 \%$ substanţă minerală, $20 \%$ substanţă organică şi $10 \%$ apă (11). Spre deosebire de smalţ, obţinerea adeziunii la nivelul dentinei este un proces complex şi sensibil. Acest lucru se explică atât prin apropierea de pulpa dentară, substanţele folosite putând avea efecte nedorite asupra acesteia, cât şi prin prezenţa tubulilor dentinari, ce conţin limfa dentinară, a cărei tendinţă de a se deplasa spre suprafaţă în urma preparării dintelui a impus dezvoltarea unor adezivi care se pot adapta umidităţii crescute (6). Astfel, în urma gravării acide a dentinei, detritusul dentar este îndepărtat împreună cu faza minerală a hidroxiapatitei, situată superficial, ducând la formarea unei reţele de fibre de colagen la suprafaţa dentinei. Hibridizarea se produce prin infiltrarea acestei trame de colagen cu monomerii din primer şi răşina adezivă şi polimerizarea lor (12).

O adevărată provocare în cadrul cavităţilor sw clasa a II-a şi a V-a o reprezintă adeziunea materialelor la nivelul cementului. Atunci când limita gingivală a cavităţilor depăşeşte joncţiunea smalţ-cement, adeziunea în această zonă este redusă, ducând în timp la microinfiltraţie marginală şi eşecul tratamentului restaurator (7). Studiile de microscopie electronică demonstrează o compoziţie semnificativ diferită a detritusului dentar remanent folosit pentru adeziunea dentinară faţă de cement, acesta din urmă având un procent crescut de substanţe or- ganice (50-55\% substanţă organică şi 45-50\% substanţă anorganică şi apă) (13). Astfel, se observăcă, după demineralizare, la nivelul cementului se formează o reţea de colagen bogată în substanţe organice, care, deşi sunt infiltrate cu monomerii răşinici, oferă o capacitate adezivă redusă (14).

\section{SCOPUL STUDIULUI}

Scopul prezentului studiu este de a evalua comparativ capacitatea adezivă a răşinilor diacrilice compozite micro- şi nanohibride la nivelul smalţului, dentinei, respectiv cementului.

\section{MATERIAL ŞI METODĂ}

Pentru atingerea scopului, s-a realizat un studiu experimental, in vitro, pe dinţi umani extraşi.

S-au utilizat 8 molari de minte maxilari extraşi în scop ortodontic sau protetic, aleşi în urma criteriilor de includere. Dinţii au fost spălaţi, curăţaţi de depozite moi şi tartru şi păstraţi în apă distilată până la preparare.

Criteriile de includere:

- molari de minte maxilari

- lipsa cariilor sau obturaţiilor pe suprafeţele vestibulare

- lipsa fracturilor coronare ce afectează suprafaţa vestibulară şi/sau camera pulpară.

Dinţii au fost împărţiţi aleator în două grupuri de câte 4 dinţi, în funcţie de tipul de particule anorganice al răşinii diacrilice compozite (microhibride sau nanohibride) cu care vor fi obturaţi, astfel:

- grupul A (4 dinţi): compozit cu particule microhibride

- grupul B (4 dinţi): compozit cu particule nanohibride.

Ulterior, fiecare grup a fost împărţit egal în două subgrupuri de câte 2 dinţi, în funcţie de prezenţa sau absenţa sub obturaţie a unei baze de compozit cu consistenţă fluidă:

- subgrupul A.1 .(2 dinţi): compozit cu particule microhibride fără bază

- subgrupul A.2. (2 dinţi): compozit cu particule microhibride cu bază

- subgrupul B.1. (2 dinţi): compozit cu particule nanohibride fără bază

- subgrupul B.2. (2 dinţi): compozit cu particule nanohibride cu bază.

S-au realizat la nivelul suprafeţelor vestibulare ale dinţilor cavităţi clasa a $\mathrm{V}$-a standardizate $(3 \mathrm{~mm}$ mezio-distal, $2 \mathrm{~mm}$ ocluzo-apical şi $2 \mathrm{~mm}$ vestibu- 
lo-oral), situate la nivelul coletului, atât în smalţ, cât şi în cement, din punctul de vedere al întinderii ocluzo-apicale. Cavităţile au fost preparate folosind iniţial o piatră diamantată efilată pentru a marca joncţiunea smalţ-cement, pe o întindere de $3 \mathrm{~mm}$ în direcţie mezio-distală, iar ulterior folosindu-se o piatră diamantată cilindrică cu inel verde (cu diametrul de $1,8 \mathrm{~mm}$ ), ambele fiind montate la turbină cu o viteză de 300.000 rpm şi răcire continuă cu apă. Dimensiunile cavităţii au fost verificate cu ajutorul unei sonde parodontale.

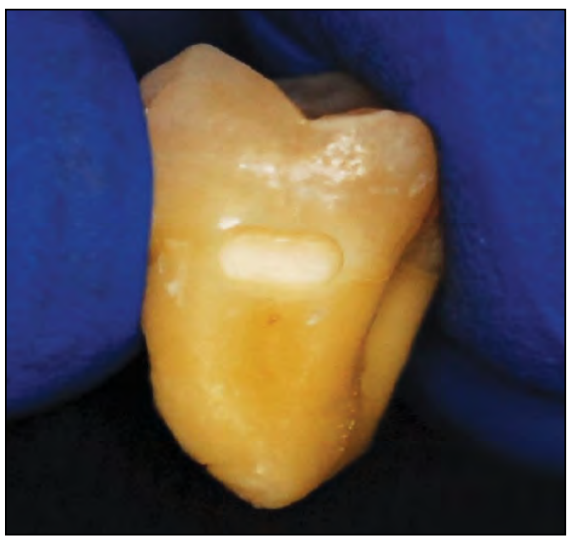

FIGURA 1. Cavitate standardizată

Prepararea cavităţilor a fost urmată de uscarea şi degresarea acestora cu o soluţie pe bază de acetonă şi acetat de etil (Hydrol - Septodont). Soluţia a fost aplicată pe o buletă de vată sterilă şi exprimată, apoi s-a realizat ştergerea pereţilor cavităţii timp de 10 secunde.

Pentru obţinerea adeziunii, s-a ales un sistem adeziv etch-and-rinse în 2 etape. Demineralizarea s-a efectuat prin gravare acidă totală, timp de 30 de secunde, cu acid ortofosforic 32\% (Scotchbond $^{\mathrm{TM}}$ Universal Etchant - 3M ESPE). După spălarea agentului demineralizant şi uscarea cu bulete de vată sterile, s-a aplicat răşina adezivă (Adper Sin- gle Bond 2 - 3M ESPE) la nivelul pereţilor dentinari ai cavităţii prin intermediul unui aplicator, care a fost ulterior fotopolimerizată cu lampa LED.

Aplicarea răşinii diacrilice compozite a succedat etapa obţinerii adeziunii şi s-a realizat în funcţie de grupurile şi subgrupurile menţionate anterior. Materialele compozite utilizate sunt prezentate în tabelul 1 .

Obturaţiile finale au fost lustruite cu gume abrazive montate la piesa contraunghi, la viteze de $30.000 \mathrm{rpm}$.

După obturare, dinţii au fost păstraţi în recipiente cu apă distilată la temperatura camerei timp de 24 de ore.

Ulterior, dinţii au fost supuşi unui proces de termociclare, care a constat în imersia alternantă a acestora în băi de apă la temperatura de $55^{\circ} \mathrm{C}$ $\left( \pm 2^{\circ} \mathrm{C}\right)$, respectiv în apă la $5^{\circ} \mathrm{C}\left( \pm 2^{\circ} \mathrm{C}\right)$. S-au realizat 300 astfel de cicluri, cu un timp de menţinere în apă de 3 secunde şi interval între cicluri de 10 secunde. Acest proces de simulare a variaţiilor de temperatură de la nivelul cavităţii orale a fost realizat manual, cu ajutorul unor suporturi metalice pentru vehicularea dinţilor între băile de apă. De asemenea, s-a utilizat un termometru digital pentru verificarea temperaturii apei şi, implicit, reglarea acesteia constant.

Următoarea etapă a constat în acoperirea dinţilor cu două straturi de lac, lăsând liberă doar o zonă de $1 \mathrm{~mm}$ grosime în jurul obturaţiei. Acest procedeu a fost realizat pentru a preveni pătrunderea ulterioară a colorantului prin apexul dintelui.

Uscarea lacului acoperitor a fost urmată de imersia completă a dinţilor în soluţie de albastru de metilen $1 \%$, timp de 24 de ore. Recipientele cu albastru de metilen au fost ferite de lumină, căldură sau alte substanţe ce îi pot afecta proprietăţile. Din-

TABELUL 1. Materialele compozite folosite pentru realizarea obturațiilor (conform datelor producătorului)

\begin{tabular}{|c|c|c|c|c|c|}
\hline Compozit/consistență & $\begin{array}{l}\text { Matrice } \\
\text { organică }\end{array}$ & $\begin{array}{l}\text { Compoziție } \\
\text { umplutură }\end{array}$ & \begin{tabular}{|l|} 
Dimensiuni particule \\
umplutură
\end{tabular} & \begin{tabular}{|l} 
Procentul umpluturii \\
raportat la masă/volum
\end{tabular} & Producător \\
\hline $\begin{array}{l}\text { Filtek } \mathrm{Z250}^{\mathrm{TM}} \\
\text { (consistență chitoasă) }\end{array}$ & $\begin{array}{l}\text { BisGMA, UDMA, } \\
\text { BisEMA }\end{array}$ & Zirconiu/silice & Microhibrid & $82 / 60$ & $3 \mathrm{M}$ ESPE \\
\hline $\begin{array}{l}\text { Filtek } \mathrm{Z550}^{\mathrm{TM}} \text { (consistență } \\
\text { chitoasă) }\end{array}$ & $\begin{array}{l}\text { BisGMA, } \\
\text { UDMA, BisEMA, } \\
\text { PEGDMA, } \\
\text { TEGDMA }\end{array}$ & Zirconiu/silice & Nanohibrid & $82 / 68$ & $3 \mathrm{M}$ ESPE \\
\hline $\begin{array}{l}\text { Gradia Direct LoFlo (3M ESPE) } \\
\text { (consistență fluidă) }\end{array}$ & UDMA & Silice prepolimerizată & Microhibrid & $40 /-$ & GC \\
\hline
\end{tabular}


ţii au fost extraşi din soluţie, urmând a fi uscaţi, etapă premergătoare înglobării în răşină.

Dinţii uscaţi au fost înglobaţi într-o răşină epoxidică (EpoThin ${ }^{\mathrm{TM}} 2$ - Buehler), lustruiţi şi secţionaţi mezio-distal cu ajutorul Beta Grinder/Polisher Buehler. S-au ales secţiunile unde era surprins cel mai mare grad al penetrării albastrului de metilen pentru a fi analizate prin microscopie optică cu lumină polarizată (Axio Imager A1m - Zeiss).

Pe baza analizei gradului de penetrare a trasorului chimic la nivelul interfeţei dinte-obturaţie, s-a realizat o scară pentru cuantificarea şi posibilitatea comparaţiei acesteia la nivelul grupurilor şi subgrupurilor.

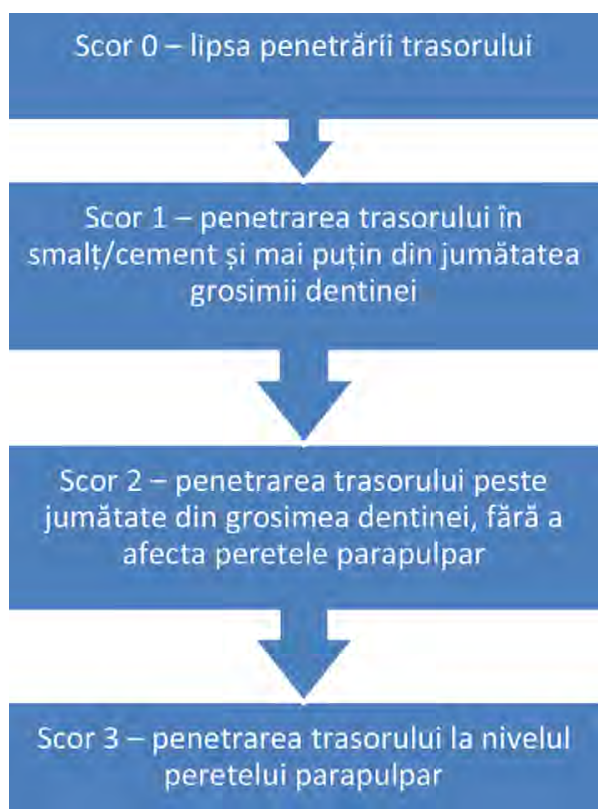

FIGURA 2. Scara gradului de penetrare a trasorului chimic

\section{REZULTATE}

În urma analizei secţiunilor la microscopul optic cu lumină polarizată, s-au detectat microinfiltraţii la nivelul tuturor dinţilor, preponderent la nivelul peretelui gingival al obturaţiei.

Rezultatele arătate în tabelul 2 indică o egalitate a scorurilor microinfiltraţiei marginale atât între subgrupuri, cât şi între grupuri.

TABELUL 2. Scorul microinfiltrației marginale

\begin{tabular}{|c|c|c|c|c|c|c|}
\hline \multirow{2}{*}{ Grup } & Subgrup & \multicolumn{2}{|c|}{ SCOR DINTE 1 } & \multicolumn{2}{c|}{ SCOR DINTE 2 } & $\begin{array}{c}\text { SCOR } \\
\text { TOTAL }\end{array}$ \\
\hline \multirow{2}{*}{ GRUP A } & A.1 & $\begin{array}{r}\text { Peretele } \\
\text { ocluzal }\end{array}$ & $\begin{array}{c}\text { Peretele } \\
\text { gingival }\end{array}$ & $\begin{array}{c}\text { Peretele } \\
\text { ocluzal }\end{array}$ & $\begin{array}{c}\text { Peretele } \\
\text { gingival }\end{array}$ & \\
\cline { 2 - 7 } & $\mathbf{A . 2}$ & $\mathbf{1}$ & $\mathbf{1}$ & $\mathbf{1}$ & $\mathbf{1}$ & $\mathbf{3}$ \\
\hline \multirow{2}{*}{ GRUP B } & B.1 & $\mathbf{0}$ & $\mathbf{1}$ & $\mathbf{1}$ & $\mathbf{1}$ & $\mathbf{3}$ \\
\cline { 2 - 7 } & $\mathbf{B . 2}$ & $\mathbf{0}$ & $\mathbf{1}$ & $\mathbf{1}$ & $\mathbf{1}$ & $\mathbf{3}$ \\
\hline
\end{tabular}

Este de remarcat faptul că scorul nu depăş̧eşte în niciunul dintre cazuri valoarea 1 .

În cadrul fiecărui subgrup există un dinte cu scorul 1 la nivelul peretelui ocluzal, însă toţi dinţii prezintă această valoare la nivelul celui gingival.

Subgrupurile cu strat intermediar compozit fluid sunt identice atât cu cele fără strat intermediar, dar obturate cu acelaşi tip de compozit (microhibrid sau nanohibrid), cât şi cu cele cu strat intermediar şi obturat cu alt tip de compozit.

\section{DISCUȚII}

O adevărată provocare în cadrul cavităţilor clasa a II-a şi a V-a o reprezintă adeziunea materialelor la nivelul cementului. În prezent, există un număr restrâns de studii despre acest subiect, rezultatele fiind, de asemenea, contradictorii. Cercetarea realizată de van Dijken et al. (1998) indică o adeziune excelentă a obturaţiilor la nivel cervical în cavităţile de clasa a II-a, deşi studiile in vitro indică microinfiltraţii medii sau severe la acest nivel $(7,15)$. Studiul lui Narayana V. et al. (2014), realizat in vitro pe 24 de molari extraşi, arată că atât compozitele hibride, cât şi cele cu nanoparticule prezintă microinfiltraţii la nivelul cementului, cu rezultatele cele mai bune în favoarea nanocompozitelor, însă este nevoie de mai multe cercetări în acest domeniu pentru înţelegerea exactă a adeziunii la cement (16).

Studiul de faţă este o dovadă în plus că adeziunea la nivelul cementului este precară, comparativ cu cea obţinută la nivelul smalţului. Comparând microinfiltraţia marginală a pereţilor ocluzali, respectiv gingivali ai obturaţiei, rezultatele sunt identice la nivelul celor două tipuri de compozit. Astfel, la toţi dinţii utilizaţi s-a observat o microinfiltraţie cu scorul 1 a peretelui gingival, în timp ce doar la 4 dinţi s-a înregistrat acelaşi scor şi la nivelul peretelui ocluzal (2 dinţi obturaţi cu compozit microhibrid şi 2 dinţi cu compozit nanohibrid). Infiltrarea tuturor dinţilor poate fi explicată de lipsa adeziunii răşinilor diacrilice compozite la nivelul cementului şi dificultatea obţinerii unei adeziuni dentinare. $\mathrm{Cu}$ toate acestea, s-a observat că la nivel gingival nu a fost depăşit în niciunul dintre cazuri scorul 1 al microinfiltraţiei, aspect extrem de important din cauza frecvenţei crescute a cariilor sau abraziunilor la acest nivel şi necesităţii existenţei unui material 


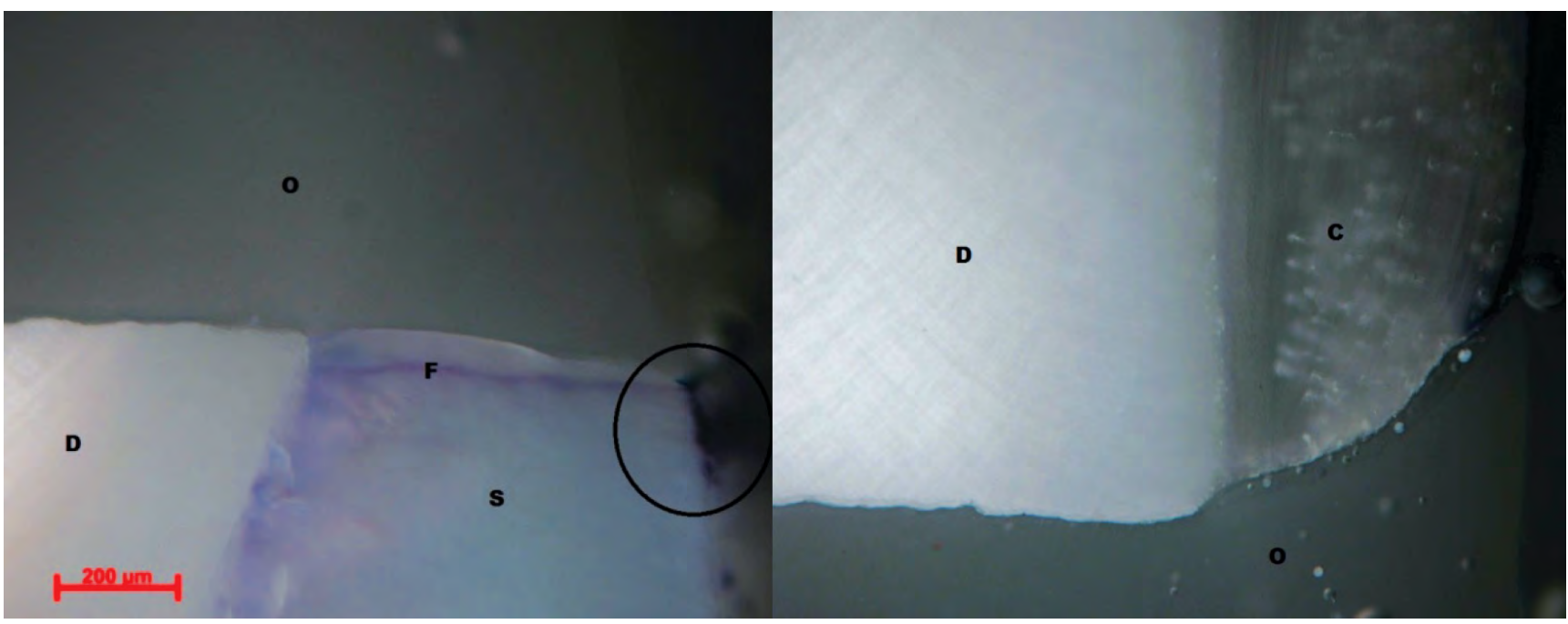

FIGURA 3. Subgrup A1. Secțiuni microscopice la nivelul pereților ocluzal (stg.) şi gingival (dr.). O - obturație, S - smalț, D dentină, F - fisură, C- cement, cerc - zonă demineralizată şi microinfiltrație redusă (lumină polarizată cu nicoli încrucişați)

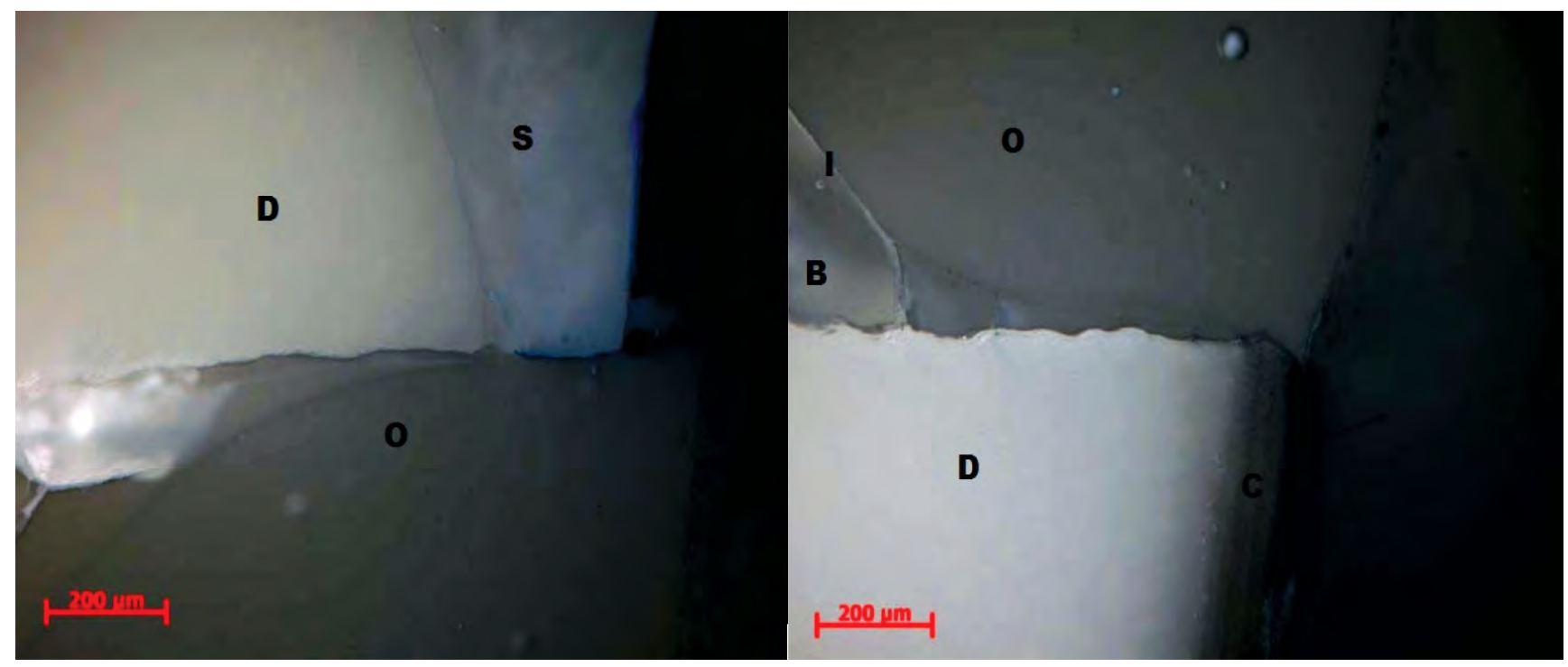

FIGURA 4. Subgrup A2. Secțiuni microscopice la nivelul peretelui ocluzal (stg.) şi gingival (dr.). O - obturație, S - smalț, D dentină, C - cement, B - bază, I - interfața obturație-bază (lumină polarizată cu nicoli încrucişați)

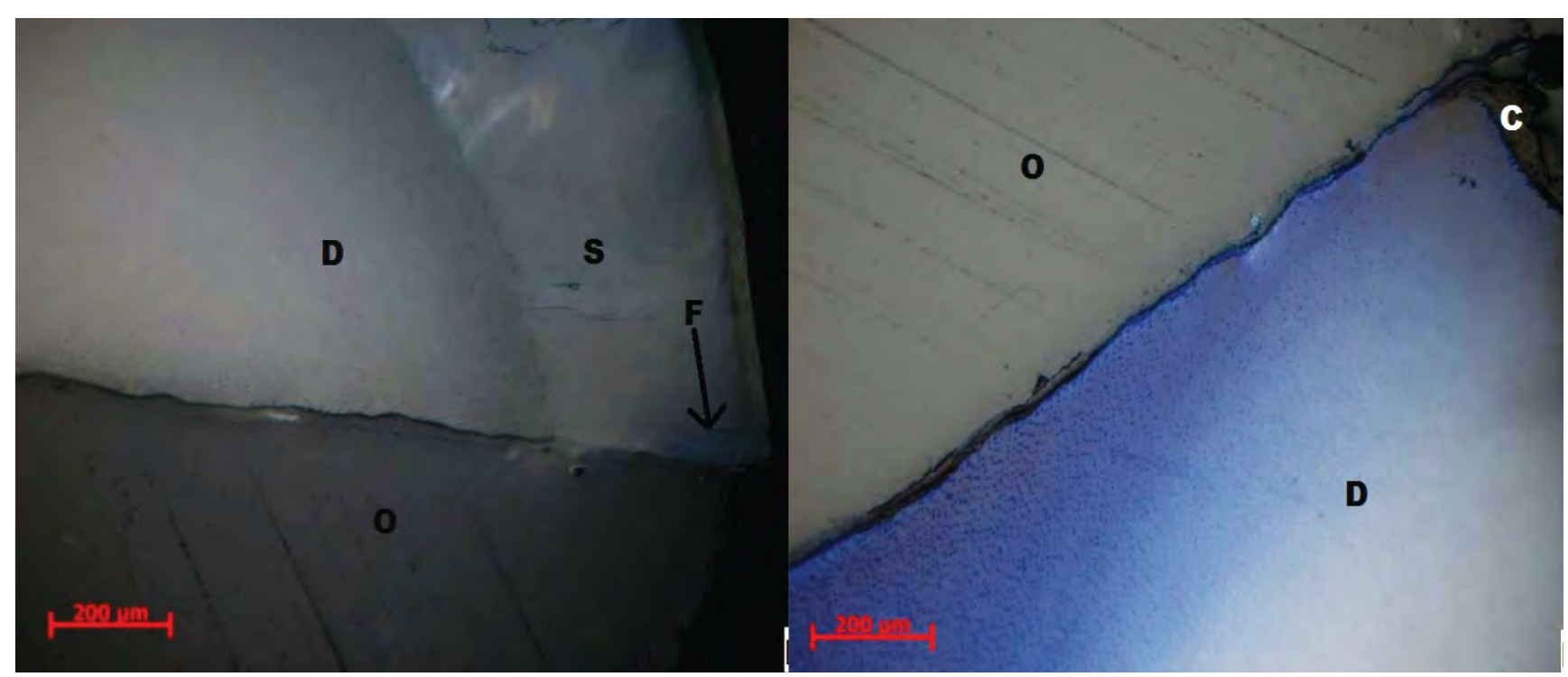

FIGURA 5. Subgrup B1. Secțiuni microscopice la nivelul pereților ocluzal (stg.) şi gingival (dr.). O - obturație, S - smalț, D dentină, F- fisură, C - cement (lumină polarizată cu nicoli încrucişați) 


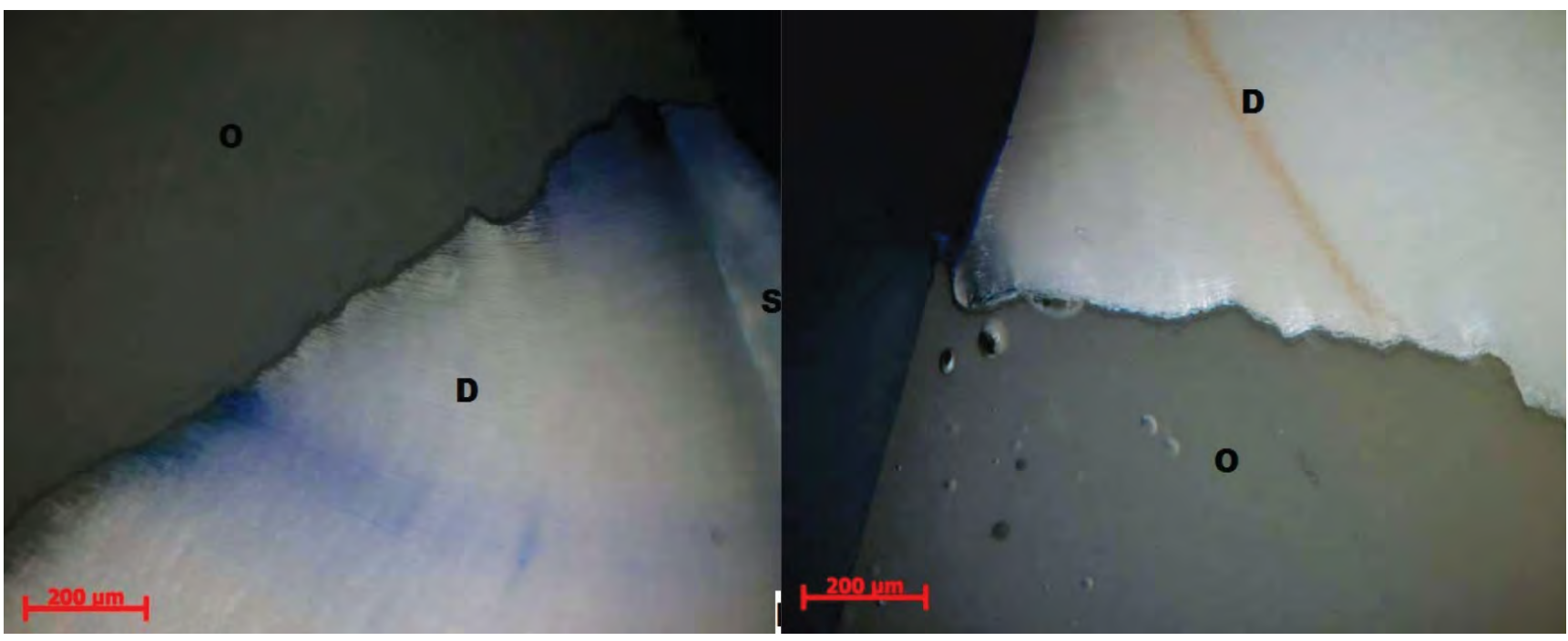

FIGURA 6. Subgrup B2. Secțiuni microscopice la nivelul pereților ocluzal (stg.) şi gingival (dr.). O - obturație, S - smalț, $D$ - dentină (lumină polarizată cu nicoli încrucişați)

care să prevină infiltrarea salivei şi a florei orale la interfaţa dinte-obturaţie.

Referitor la tipurile de compozit utilizate, atât cel cu particule microhibride, cât şi cel cu nanohibride au prezentat microinfiltraţie marginală, în ambele cazuri înregistrându-se un scor total de 6 pentru fiecare dintre grupuri. $\mathrm{Cu}$ toate acestea, în niciunul dintre cazuri nu s-a depăşit scorul 1. Astfel, nu există nicio diferenţă între cele două materiale (Z250 - microhibrid şi Z550 - nanohibrid) din punctul de vedere al microinfiltraţiei marginale. Acest rezultat este în concordanţă cu studiul lui Ebrahim Yarmohamadi et al. (2018), care a concluzionat că nu există o diferenţă statistică semnificativă între microinfiltraţia marginală a compozitelor cu particule microhibride, nanohibride şi ormoceri (17). Aceleaşi rezultate au fost confirmate şi de Saumya et al. (2017), într-un studiu in vitro pe 160 de dinţi umani extraşi, folosind compozite fluide (18).

Cercetările din domeniu au arătat faptul că folosirea unui strat intermediar (bază) de compozit fluid are influenţe pozitive asupra obturaţiei $(19,20)$. Reducerea microinfiltraţiei marginale, a contracţiei de polimerizare şi creşterea adaptării interne a compozitului reprezintă avantaje ale folosirii stratului intermediar de compozit fluid datorită conceptului peretelui elastic (21). Există însă şi studii ce contrazic existenţa acestor avantaje $(22,23)$.

În prezentul studiu, s-a arătat că nu există diferenţe ale gradului de microinfiltraţie între obturaţiile cu particule microhibride şi cele nanohibride care au primit straturi intermediare de compozite fluide. Astfel, în ambele subgrupuri (A.2 şi B.2), microinfiltraţia marginală a ajuns la scorul 1 la nivelul tuturor dinţilor în peretele gingival, în timp ce în fiecare subgrup a existat un dinte care a prezentat scor 1 şi la nivelul peretelui ocluzal. De asemenea, comparând subgrupurile între ele la nivelul aceluiaşi grup (A.1 faţă de A.2 şi B.1 faţă de B.2), se constată că nu există nicio diferenţă din punctul de vedere al microinfiltraţiei între dinţii fără, respectiv cu strat intermediar.

Aşadar, se remarcă egalitatea rezultatelor subgrupurilor şi, astfel, lipsa diferenţelor dintre cele două tipuri de răşini diacrilice compozite în ceea ce priveşte microinfiltraţia marginală. Rezultatele sunt însă optimiste; penetrarea trasorului chimic mai puţin de jumătate din grosimea dentinei adiacente obturaţiei, precum şi existenţa unor dinţi cu scor 0 la nivel ocluzal indică o adeziune satisfăcătoare şi posibilitatea utilizării acestor materiale în cavităţile de clasa a V-a.

Trebuie ţinut cont, în ciuda egalităţii microinfiltraţiei dintre cele două categorii de compozite, şi de lustruirea superioară de care dau dovadă răşinile diacrilice compozite cu particule nanohibride, care se realizează fără desprinderea unor fracţiuni mari de umplutură ce lasă suprafeţe poroase sau chiar microcavităţi în apropierea interfeţei dinte-obturaţie, spaţii propice pentru penetrarea microorganismelor (24).

Cercetările continuă însă în încercarea de a obţine un grad de adeziune optim la nivelul tuturor ţe- 
suturilor dure dentare. Astfel, s-a descoperit faptul că tratarea cementului cu o soluţie apoasă de hipoclorit de sodiu, anterior adezivului, poate duce la reducerea procentului crescut de substanţe organice. Datorită lipsei de mineralizare a fibrelor intrinseci, acţiunea hipocloritului poate fi sporită prin acţiunea de frecare. Aşadar, o soluţie de hipoclorit de sodiu $10 \%$ poate acţiona ca un condiţionant pentru cement (7).

Prezentul studiu are o serie de limitări. Eşantionul folosit este redus, împiedicând o evaluare amplă a microinfiltraţiei. De asemenea, trebuie menţionate şi lipsa folosirii unui proces tehnologic pentru termociclare şi lipsa controlului asupra perioadei

\section{BIBLIOGRAFIE}

1. Van Meerbeek B, Perdigão J, Lambrechts P \& Vanherle G. The clinical performance of adhesives. Journal of Dentistry 1998. 26(1) 1-20.

2. Peumans M, Kanumilli P, De Munck J, Van Landuyt K, Lambrechts $P$, Van Meerbeek B. Clinical effectiveness of contemporary adhesives: A systematic review of current clinical trials. Dental Materials 2005. 21(9) 864-881.

3. Forss $\mathrm{H}$, Widström $\mathrm{E}$. From amalgam to composite: selection of restorative materials and restoration longevity in Finland. Acta Odontologica Scandinavica 2001. 59(2) 57-62.

4. Mjör IA, Shen C, Eliasson ST, Richter S. Placement and replacement of restorations in general dental practice in Iceland. Operative Dentistry 2002. 27(2) 117-123.

5. Sakaguchi R, Powers J. Craig's Restorative Dental Materials. 13th ed: Mosby; 2012. p. 135-45, 61-82, 327-33.

6. Nicholson JW. The Chemistry of Medical and Dental Materials. Cambridge: RSC Materials Monographs; 2002. p. 149-58.

7. Tziafas D, Eliades G. Strategies for Bonding to Root Dental Structures. In: Eliades G, Watts D, Eliades T, editors. Dental Hard Tissues and Bonding. Berlin: Springer-Verlag; 2005.

8. Shabayek NM, Hassan FM, Mobarak EH. Effect of using siloranebased resin composite for restoring conservative cavities on the changes in cuspal deflection. Oper Dent. 2013;38:42-49.

9. Fehrenbach M, Popowics T. Illustrated Dental Embryology, Histology, and Anatomy. 4th ed. Missouri: Elsevier Saunders; 2015. p. 147-52.

10. Gwinnett AJ, Matsui A. A study of enamel adhesives. The physical relationship between enamel and adhesive. Archives of Oral Biology. 1967;12:1615

11. Nanci A. Oral Histology: Development, Structure and Function. St. Louis: Mosby; 2003.

12. Özcan M, Dundar M, Erhan M. Adhesion aspects in dentistry: Tooth and restorative materials. Journal of Adhesion Science and Technology, Volume 26, 2012 - Issue 24, 2661-2681.

13. Popa M, Bodnar DC, Vârlan CM. Manual de odontoterapie restauratoare. Editura Universitară „Carol Davila”, Bucureşti, 2007. p. 21-87.

14. Eliades G, Palaghias G, Vougiouklakis G. Bonding composites to cementum by Gluma: surface characterization and bond strength. J Dent Res. 1991;70:383. de timp parcurse de la extracţia dintelui până la preparare.

\section{CONCLUZII}

$\mathrm{Cu}$ toate limitele prezentului studiu, putem concluziona că adeziunea celor două tipuri de răşini diacrilice compozite este optimă la nivelul smalţului, cementul prezentând grade avansate de microinfiltraţie.

$\mathrm{Nu}$ există diferenţe între microinfiltraţia marginală a obturaţiilor cu, respectiv fără strat intermediar de compozit fluid.

15. van Dijken JW, Hörstedt P, Waern R. Directed polymerization shrinkage versus a horizontal incremental filling technique: Interfacial adaptation in vivo in class II cavities. American Journal of Dentistry. 1998;11(4):165-72.

16. Narayana V, Ashwathanarayana S, Nadig G, Rudraswamy S, Doggalli N, Vijai S. Assessment of Microleakage in Class II Cavities Having Gingival Wall in Cementum using Three Different Posterior Composites. Journal of International Oral Health: JIOH. 2014; 6(4):35-41.

17. Yarmohamadi E, Jahromi P, Akbarzadeh M. Comparison of Cuspal Deflection and Microleakage of Premolar Teeth restored with Three Restorative Materials. J Contemp Dent Pract 2018;19(6):684-9.

18. Saumya., Dhingra R, Gupta A, Karunanand B. Comparative Evaluation of Fracture Resistance and Microleakage of Reattached Anterior Tooth Fragment Using Two Different Flowable CompositesAn in vitro Study. British Journal of Medicine and Medical Research. 2017; $211-10$.

19. Tung F, Estafan D, Scherer W. Microleakage of a condensable resin composite: An in vitro investigation. Quintessence International. 2000; 31(6):430-4.

20. Peutzfeldt A, Asmussen E. Composite restorations: influence of flowable and self-curing resin composite linings on microleakage in vitro. Operative dentistry. 2002;27(6):569-75.

21. Kemp-Scholte CM, Davidson CL. Complete marginal seal of Class $V$ resin composite restorations effected by increased flexibility. J Dent Res. 1990;69(6):1240-3.

22. Güngör HC, Canoğlu E, Cehreli ZC. The effects of dentin adhesives and liner materials on the microleakage of class II resin composite restorations in primary and permanent teeth. $J$ Clin Pediatr Dent. 2014 Spring; 38(3):223-8.

23. Boruziniat A, Gharaee S, Sarraf Shirazi A, Majidinia S, Vatanpour M. Evaluation of the efficacy of flowable composite as lining material on microleakage of composite resin restorations: A systematic review and meta-analysis. Quintessence Int. 2016 Feb;47(2):93-101.

24. Magdy NM, Kola MZ, Alqahtani HH, Alqahtani MD, Alghmlas AS. Evaluation of Surface Roughness of Different Direct Resin-based Composites. J Int Soc Prev Community Dent. 2017 May-Jun; 7(3):104-109. 